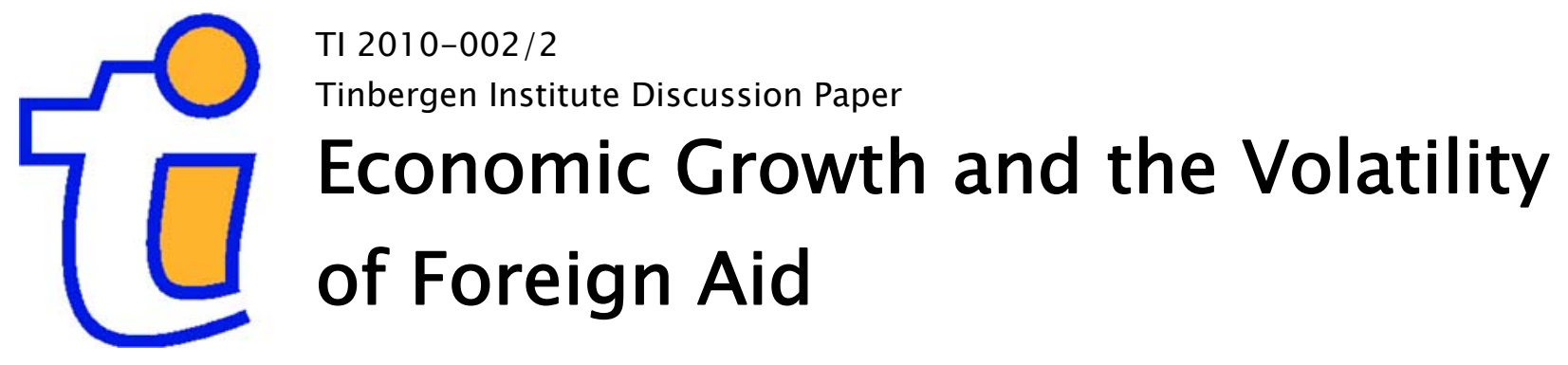

Michal Chervin'

Sweder van Wijnbergen ${ }^{1,2}$

1 University of Amsterdam;

2 Tinbergen Institute. 


\section{Tinbergen Institute}

The Tinbergen Institute is the institute for economic research of the Erasmus Universiteit Rotterdam, Universiteit van Amsterdam, and Vrije Universiteit Amsterdam.

Tinbergen Institute Amsterdam

Roetersstraat 31

1018 WB Amsterdam

The Netherlands

Tel.: +31(0)205513500

Fax: $+31(0) 205513555$

Tinbergen Institute Rotterdam

Burg. Oudlaan 50

3062 PA Rotterdam

The Netherlands

Tel.: + $31(0) 104088900$

Fax: $+31(0) 104089031$

Most TI discussion papers can be downloaded at http://www.tinbergen.nl. 


\title{
Economic Growth and the Volatility of Foreign aid
}

\author{
December 2009 \\ Michal Chervin \\ University of Amsterdam \\ and \\ Sweder van Wijnbergen* \\ University of Amsterdam en Tinbergen Institute
}

Foreign aid's effectiveness in promoting economic growth remains mired in controversy.We examine the impact of the volatility of aid on economic growth, controlling for the level of aid. A four-year panel analysis is conducted encompassing 155 countries over the period 1966-2001. We find that once the volatility of aid is controlled for, aid has a positive impact on economic growth. Correspondingly, volatility of aid flows is found to be negatively related to growth. We found no significant link between investment and foreign aid, but a positive correlation between aid and consumption and a negative link between aid volatility and consumption. But our results also indicate that aid has become a source of volatility rather than insuring against it, and in that way may have become inimical to economic growth.

Key Words: foreign aid, volatility, economic growth JEL codes: O4, O11, O19

*Corresponding author. We are indebted to J.W. Gunning for many helpful comments and to Ann Case for insightful suggestions on how to interpret some of the econometric results. 


\section{Contents}

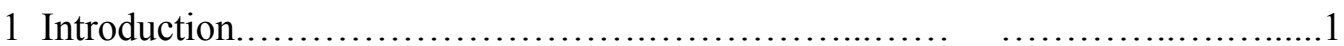

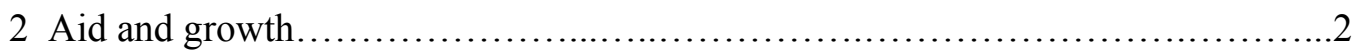

2.1 Review of recent literature on the aid-growth relationship..... $\quad .2$

2.1.1 Foreign aid increases economicgrowth............. $\quad \ldots \ldots . .3$

2.1.2 Foreign aid hinders economic growth................... 4

growth ...--...._. 5

2.2 Volatility of aid flows................-..........................6

3 Empirical setup..................................................... 8

3.1 Description of explanatory variables..................... $\quad \ldots \ldots \ldots 8$

3.2 data...........................................................

3.3 Regression specification..................................... 12

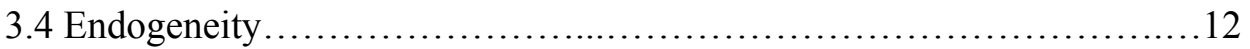

4 Empirical results and analysis.......................................... 14

4.1 Robustness checks.................................................. 16

5 Channels through which aid impacts growth............................... 19

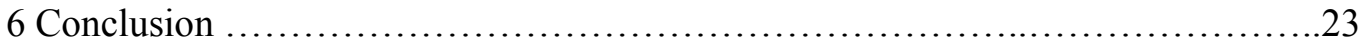

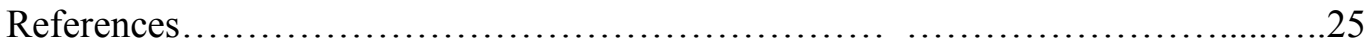

Appendix 1 - Descriptive statistics .......................................29

Appendix 2 - Country list.................................................. 30

Appendix 3 - Data set............................................... 31

Appendix 4 - Additional specifications..................................32 


\section{Introduction}

The international community has recently ${ }^{1}$ committed to significantly scaling-up the amount of foreign aid to low-income countries over the coming decade with the aim of helping them meet the Millennium Development Goals (MDGs). Specifically, donors have committed to double aid to sub-Saharan Africa (SSA) by 2010 (IMF, 2007).

The underlying argument for Official Development Assistance (hereafter 'foreign aid') to low-income countries rests on the limited ability of many of these countries to raise sufficient resources through taxation and/or private capital markets. External finance through non-market channels is therefore, according to this view, essential to sustain long-term public investment in infrastructure, health and education programs as well as promote economic growth. Yet the emprirical link between development aid and various indicators of economic growth has remainded controversial since the early work by Boone (1996). A huge literature has followed Boone's work, by and large leaving his sceptical conclusions intact. However, despite the importance and the potential benefits of foreign aid, limited attention has been paid to the consequences of aid volatility. It is in this area where this paper seeks to contribute.

Buliřr and Hamann (2005) find that foreign aid flows tare roughly 40 times more volatile than tax revenues and that volatility has actually been on the rise since the late 1990s. Particularly low-income countries in Sub-Saharan Africa have experienced the highest yearly fluctuation in aid flows. Volatile aid flows may affect growth through their implications on the design of intertemporal fiscal policies by recipient governments. It may further make it more difficult for these governments to formulate domestic investment and consumption plans. Volatile aid may also be harmful to the business climate and thereby slow down private investment.

Volatile aid flows which give rise to windfalls of funds may impact the competitiveness of the receiving economy and cause the exchange rate to appreciate, a phenomenon termed 'Dutch Disease' in the literature. Van Wijnbergen(1984) and Caballero (2007) show that DD problems mostly arise when windfall gains are temporary, so volatile aid flows are more likley to be damaging through this channel 
than smooth aid flows. In this case, the competitiveness of the country is often harmed. Conversely, as foreign aid often finances a large fraction of infrastructure projects in developing countries, shortfalls may freeze these processes unless alternative means of funding are available. This is often the case, as resources for such investments take time to acquire (Rajan, 2005).

Drawing on the existing empirical literature on the aid-growth relationship, this paper concentrates on the aid-growth relationship at the macro-level and, more

specifically, examines the impact of the volatility of aid on economic growth controlling for the level of aid. To do this, a four-year panel analysis is conducted encompassing 155 countries over the period 1966-2001.

The paper is organized as follows. Section 2 provides a background discussion of the aid-growth link as well as an overview of the current literature on the topic. Section 3 contains the model specification, a description of the explanatory variables and data. Section 4 presents an analysis of the empirical results, while section 5 investigates the channels through which foreign aid impacts economic growth. Section 6 concludes.

\section{Aid and growth}

The apparent lack of growth in many developing countries has initially been attributed to the shortage of capital (or low saving) as well as foreign exchange constraints. From this perspective, foreign aid is considered vital for closing the gaps between savings and investment, and between exports and imports and thereby allowing growth in the economy to take off. It appears, however, that growth of many developing countries has faltered despite massive aid flows. On top of that, the more foreign aid these countries have received, the more aid dependent they have become, binding them into a debt trap according to many observers.

Turning to the volatility of aid, the consequences for aggregate growth were found by several studies to be very high (Lensink and Morrisey, 2000, Bulír and Hamann, 2003, Pallage and Robe, 2003). Aid delivered in an unreliable manner can apparently diminish its potential benefits. Before turning to a discussion of the potential 
consequences of volatile aid flows, we provide a short overview of the literature on the aid-growth relationship.

\subsection{Review of recent literature on the aid-growth relationship}

There is an abundance of empirical literature on the aid-growth relationship, but no consensus on the impact of aid on growth has emerged., The ambiguity concerns not just the size of the effect, if any, but even its sign, with the numerous studies often displaying conflicting as well as ambiguous results. This lack of consistency stems from various reasons including regression specifications and technique, data quality and sample size, as we discuss below. The literature reports alternatively positive, negative and no effects. We sort the literature reviewed below in studies respectively reporting positive, negative or no effects of aid on growth.

\subsubsection{Foreign aid increases economic growth}

The notion that foreign aid flows promote economic growth is based on early models for the determination of the aid-growth relationship which assume that physical capital accumulation is the key to economic growth. Among the earliest of these models is the Harrod Domar growth model which was expanded later in the Chenery and Strout twogap model. Chenery and Strout (1966) asserted that foreign aid increases growth by alleviating the two constraints regarding physical capital accumulation which characterize many developing countries, namely, the savings constraint and the foreign exchange constraint.

Among those studies finding a significant positive correlation between foreign aid and economic growth is the one conducted by Papanek (1973), who was the first to regress growth on aid. Papanek (1973) separated aid from other types of foreign capital and empirically examined the relationship between foreign aid, saving and foreign private investment. He maintained that foreign aid should be directed at countries suffering from a balance of payments constraint. Papanek's study suffers from 
econometric flaws such as simultaneity and measurement problems and thus remains controversial (Ali and Isse, 2005).

In a separate study, Levy (1988) examines the relationship between aid and growth in sub-Saharan Africa and finds a significant positive correlation between aid and investment as well as between aid and economic growth in Africa. Similarly, Singh (1985), Hadjimichael et al. (1995) and Dowling and Hiemenz (1983) all find a positive and significant impact of foreign aid on growth. Clemens et al. (2004) distinguish between short-impact aid and long-impact aid and find a strong and positive effect of aid on growth.

\subsubsection{Foreign aid hinders economic growth}

There are several reasons as to why foreign aid may be inimical to economic growth. One line of argument attributes the negative impact of foreign aid on growth to government actions. Since foreign aid expands a government's resource envelope, it often relaxes its tax raising efforts and thus results in reduced tax revenues. The country's tax raising mechanisms may subsequently deteriorate triggering the need for additional aid while dissipating the short-term beneficial effects of aid and creating a culture of dependency (Adam and O'Connell, 1999). Moreover, many critics of foreign aid refer to the tendency of large capital inflows to reduce government fiscal discipline (Levy, 1988). A larger resource envelope may have a corrupting influence on governments since it relaxes its need to explain its actions to citizens.

A further important negative effect of foreign aid on growth involves a phenomenon termed the 'Dutch Disease'. The mechanism is as follows. When a part of the large windfalls of resources (in this case foreign aid) is spent on non traded goods and services in the domestic country, an excessive demand for this type of goods and services arises. As imports cannot satisfy this excess demand and due to domestic supply constraints, the price of non-tradable goods and services will consequently increase relative to the price of tradable goods. The subsequent appreciation of the real domestic exchange rate results in the loss of external competitiveness which, in turn, could lead to lower economic growth in the long-run (van Wijnbergen 1984) ${ }^{2}$.

Van Wijnbergen (1984) argues that the problem mostly arizes when windfall revenues are temporary. ${ }^{2}$ See also Caballero (2007) for a similar point, focusing on financial market imperferctions. 
The theory of 'Dutch Disease' offers a possible explanation of the negative correlations between aid and growth found in numerous studies. One example is the study conducted by Rajan and Subramanian (2006) who employ a methodology which exploits both cross-country and within-country variation in the data. Their results suggest that aid depresses the average growth rate of the manufacturing sector in a country and that the channel through which this effect is felt is the exchange rate overvaluation induced by aid flows. The study does suffer from data problems in that manufacturing growth itself is measured in a way that makes it arithmetically depend negatively on their definition of the real exchange rate by the choice of price index used to deflate industrial output (they use the general GDP deflator instead of (a proxy for) industrial output prices.

\subsubsection{Insignificant relationship between foreign aid and economic growth}

As advances in growth theory have recently illustrated, a host of interdependent factors besides physical capital accumulation affect the growth process. According to many studies, therefore, the problem with the Harrod-Domar growth model and the Chenery and Strout two-gap model is their oversimplification (Moreira, 2003). Much of the current literature argues that the specific effect of foreign aid depends on various other factors, among them, sound macroeconomic policies and geographical location.

An influential paper by Burnside and Dollar (2000) found that aid spurs growth, but only in countries with sufficiently good macroeconomic performance and institutions. In their regressions, Burnside and Dollar (2000) include an interaction term of aid and an index of recipient country policies (aid $x$ policy). However, aid $x$ policy only becomes significant when outlier observations are excluded, or a quadratic interaction term (aid ${ }^{2} x$ policy) is added. In the latter specification, both aid $x$ policy and $a_{i d}^{2} x$ policy enter significantly positive and negative respectively. Burnside and Dollar (2000) then conclude that foreign aid increases growth in countries with a good policy environment, but with diminishing returns. The robustness of their results, however, has been criticized by Easterly, Levine, and Roodman (2004), among others.

Foreign aid's contribution to growth may also depend on other factors besides policy, as was suggested in a recent study by Dalgaard et al. (2004). They view tropical 
area as an exogenous determinant of growth and include aid and aid $x$ tropical area fraction in their regressions. Both terms turn out significant, the first with a positive sign while the second with a negative sign. The sum of the two coefficients is indistinguishable from zero for countries situated completely in the tropics. Hence, on average, aid seems to work outside the tropics but not inside them. There rationale for the ineffectiveness of aid inside the tropics remains unclear. Rather than an explanation, this result may simply be a way of separating countries where aid has been effective from those where it has not. From a policy perspective, however, most of the poorest countries are situated inside the tropics and it is there where aid is especially important (Roodman, 2004).

Studies which have found insignificant aid coefficients include Mosley et al. (1987), Voivodas (1973) and White (1992). Lensink and Morrisey (2000) find that the effect of aid on growth is insignificant unless they control for uncertainty of aid inflows. There are many possible explanations for an insignificant effect of aid on growth. It may be the case that aid is not directly intended for investment, but intended for humanitarian purposes. Alternatively, due to dishonest and corrupt behavior by recipients, aid may be diverted from intended investment. It may further be the case that the productivity of the investment is low due to factors such as poor economic policy. Finally, the insignificant effect may, as is discussed next, be due to the consequent uncertainty inflicted by volatile aid flows.

\subsection{Volatility of aid flows}

So far, the current literature on the aid-growth link has been reviewed. The aim of this paper, however, is to draw attention to a previously neglected factor in the aid-growth literature, namely, the volatility of foreign aid flows. In terms of its contribution to economic growth, such volatility may influence the effectiveness of aid. ${ }^{3}$. Studies such as Bulír and Hamann (2003, 2005) and Chauvet and Guillaumont (2008) have looked at the volatility of foreign aid flows, but only one paper has investigated the link between economic growth and volatile aid - Lensink and Morrissey (2000). 
Bulír and Hamann $(2003,2005)$ empirically assess the various aspects of the cyclical behavior of aid flows and note that the volatility of aid flows greatly exceeds that of other macroeconomic variables, including GDP and fiscal revenue. Thus, aid flows, if volatile aid can potentially contribute to macroeconomic instability. Chauvet and Guillaumont (2008), on the other hand, examine the impact of aid on the volatility of income. While they find aid to be stabilizing, its volatility is found to have a destabilizing impact. Finally, Lensink and Morrissey (2000) examine the uncertainty of foreign aid employing a dataset covering 75 countries for the period 1975-1995. Their results suggest that uncertain and unpredictable aid flows impede growth while stable and predictable aid flows encourage it.

This paper tests the impact of volatile aid flows on economic growth, like to Lensink and Morrissey (2000). But more data have become available and over a longer time period since their study. The longer time series make it possible to exploit time variation through panel methods (Lensink and Morrissey (2000) use cross-section methods). Furthermore, the country coverage is greatly extended in this paper, from 75 to 155 countries. Finally we use a wider definition of volatility. Lensink and Morissey (2000) focus on predictability (like Celasun e.a. (2007)), i.e. the variance of the "unexplained" component of aid-to-gdp time series. They do so by estimating simple univariate first order VARs for aid-to-gdp ratios, and use the estimated standard deviation of the regressions as explanatory variables in otherwise conventional crosssection growth regressions. We use a wider definition of volatility: we look at actual volatility, whether predictable or not. The reason why volatility matters at all is because recipients have insufficient access to capital markets to offset income volatility; that is why they get aid to begin with. However, capital markets do more than offering insurance, for which the unanticipated component of volatility matters. Capital markets also allow smoothing over perfectly anticipated changes in income; conversely, not having access to capital markets means that perfectly anticipated fluctuations may cause problems too. Therefore we use an actual measure of volatility rather than confining us to unanticipated volatility like lensink and Morrissey (2000).

Endogenous growth theory, which motivates the work on the aid-growth relationship, does not provide a direct link between aid and growth, or between aid volatility and growth. Rather, aid can be expected to influence growth through its effect 
on factors such as investment and government behavior. Since foreign aid is a source of government revenue, volatile aid flows translate into unstable revenue, and may thus alter fiscal behavior regarding taxation and public investment decisions. Gemmell and McGillivray (1998) revealed that unpredicted shortfalls in aid tended to lead to a decline in government expenditure as well as in increases in taxes

A further effect of aid on growth is likely to arise through investment behavior, both directly through public investment and indirectly through its effect on private investment. Factors impacting investment behavior are therefore central to the discussion on the effect of aid on economic growth. This paper tests the link between investment and aid volatility; the results are presented in section 6. First, however, the aid-growth link is assessed.

\section{Empirical setup}

This section offers a description of the explanatory variables, data and model specification employed in the analysis. Later, a discussion of the endogeneity problem is provided as well as an explanation of the variable used to instrument foreign aid.

\subsection{Description of explanatory variables}

\section{Aid}

The OECD definition of Official Development Assistance (ODA) aggregates numerous categories including balance of payments support, project and program aid, technical cooperation, debt relief and humanitarian aid, among others. As a result of the large heterogeneity among the components of foreign aid, the utilization of an aggregate measure maybe problematic

An additional dimension to the problem concerning the heterogeneity of foreign aid, involves conditionality. Foreign aid is often disbursed to recipients which follow IMF-supported programs and that are considered to be 'on track' to meeting certain conditions. Yet other disbursements may depend on donor-recipient interactions. In this sense, volatile aid flows may mirror difficulties with project implementation, 
compliance with conditionality or perhaps interruptions to the regular disbursement process, stemming from the donor country (Bulír and Hamann, 2003).

As pointed out by Bulír and Hamann (2003), almost no differentiation among the various categories of aid has been attempted by cross-country studies due to insufficient data (cf Clemens, Radelet aand Bhavnani (2004) for an exception). The few studies which have distinguished among these categories have largely obtained inconclusive results. Therefore we use the composite OECD definition of foreign aid as a share of GDP in the subsequent analysis. The actual standard deviation of this variable is then used to capture the volatility of aid, as indicated in the previous ssection.

\section{Macroeconomic policy}

Recent studies have emphasized a sound macroeconomic policy environment as an essential condition for the effective implementation of foreign aid. It is argued that policies such as financial repression lower the efficiency of capital investment and thus the rate of growth. In contrast, the evidence suggests that low and stable inflation levels, sustainable fiscal policy and a balance of payments which is perceived as viable, all contribute to faster growth for a given level of investment (Durbarry et al., 1998). As a result of the work of Easterly and Rebelo (1993) and Fischer (1991, 1993), this issue has become subject to increased systematic investigation.

According to Fischer (1993), inflation rates tend to reflect the ability of the government to manage the economy. Higher inflation levels tend to be more unstable and are generally associated with poor macroeconomic performance implying that the government has lost control. Also, high inflation tends to lead to higher relative price volatility as price adjustments are not always synchronized, thereby diluting the information content of relative price signals. A history of high inflation rates, therefore, is a negative signal to investors about the credibility of the government and the instability of the economy. In light of these arguments, the analysis in this paper utilizes $\log (1+$ inflation $)$ to proxy for macroeconomic instability and a negative sign is hypothesized for the coefficient.

Also, M2 as a proxy of financial development has been incorporated in much of the literature, as a percentage of GDP. It is included in the regressions and lagged one period to avoid endogeneity problems (aid inflows could lead to concurrent 
moneysupply increases). Financial development is thought to spur growth through the enlargement and improvement of the services offered by financial intermediaries, such as savings mobilization, project evaluation and risk management.

\section{Human capital and physical capital}

Further variables included in much of the current aid literature are (the level of) human capital and physical capital. The investment share over GDP is used to proxy changes in physical capital endowment. It is lagged one period to reflect the time needed for the benefits of investments to surface ("time to build"). Since higher investment leads to higher growth rates, a positive sign is expected for the coefficient. Of course investment itself may be affected by volatility (Dixit and Pindyck, Cukierman ( ), among others). We will inspect that channel in section 5.

Human capital plays an important role as a key input to the sectors which generate or implement new ideas or products Countries with larger stocks of human capital thus tend to grow faster as they experience a faster rate of introduction of new technology (Barro, 1991, Benhabib and Siegel (1995)). The level of human capital is proxied in this paper by mean years of schooling of those over the age of 25 and is expected to have a positive coefficient.

\section{Additional control variables}

A standard control variable used in the literature is a proxy for the initial level of per capita GDP, which is included to verify the convergence hypothesis. As was brought to attention by Barro (1991) and according to neoclassical growth models, a country's per capital growth rate tends to be inversely related to its initial level of per capita GDP. Specifically, if countries are similar expect for their starting income levels, poor countries are predicted to grow faster than rich countries. The coefficient of initial GDP per capita is therefore expected to have a negative sign.

An additional variable included in the regressions is a measure of the quality of institutional settings in a country. Since economic policies are formulated and implemented within such settings, good institutions - such as efficient bureaucracy, effective judiciary, and lower level of government corruption - are expected to be correlated with faster growth. On the other hand, poor institutions may be harmful to 
economic growth by, for instance, reducing entrepreneurial activities and negatively influencing investment behavior. The quality of institutions is assumed to change slowly over time and thus captures the long-term characteristics of countries affecting policies as well as growth. This variable is expected have a positive sign.

To capture civil unrest, the analysis includes a variable measuring political instability. The variable is a simple average of assassinations per capita and revolutions per year. A political instability variable has surfaced in a number of studies including Burnside and Dollar (2000) and Easterly and Levine (1997) and found to be negatively correlated with long-run economic growth. Similarly, it has been previously suggested that ethnic diversity influences economic performance (Easterly and Levine, 2001). A variable measuring ethnic fractionalization is thus added to the regressions. It measures the probability that two randomly selected individuals from a given country will not belong to the same ethnolinguistic group.

Two additional variables included in the analysis are population growth and the fraction of the country situated in the tropics. The latter has been cited in several studies including Dalgaard et al. (2004), Bloom and Sachs (1998) and Sachs (2001, 2003) and has been found to enter significantly in the growth regressions. Population growth is added to proxy for labor force growth and a positive sign is expected.

\subsection{Data}

The data employed in this paper cover 155 countries over the period 1966-2001. Foreign aid data were drawn from OECD data of Official Development Assistance (ODA). The data on institutional quality, political instability, tropical area fraction, ethnic fractionalization, mean years of secondary schooling, population growth, inflation, M2/GDP and initial GDP were obtained from the Anarchy of Numbers data set by Roodman (2004) retrieved from the Center for Global Development website. The data on real GDP, investment share of real GDP and openness were obtained from the Penn World Table 6.2. ${ }^{4}$ 


\subsection{Regression specification}

The specification of the growth regression estimated in this paper can be written as follows:

$$
\begin{aligned}
& \hat{y}=\alpha+\beta_{1}(\text { Aid } / G D P)+\beta_{2}(\text { Aid volatility })+\beta_{3}(\text { Control variables })+\varepsilon \\
& \hat{y}: G D P \text { growth per capita }
\end{aligned}
$$

The dependent variable is real per capita GDP growth while the control variables are those discussed in the previous section. The variables of interest in the above regression are Aid Volatility and Aid/GDP. Four-year averaged data are used in the analysis in order to eliminate business cycle factors and reduce measurement error and a pooled OLS regression is performed. Robustness checks are also performed and presented in section 4.2 where we also try out different ways of structuring the assumed covariance matrix (fixed and random effects regressions).

\subsection{Endogeneity}

Before proceeding to a discussion of the results, the problem of endogeneity should be addressed. Foreign aid influences and is influenced by the recipient country's economic growth. Donors may be motivated to give aid to poorly performing countries with lower growth levels, or conversely, they may prefer giving aid to successful recipients with high growth levels. The possibility that foreign aid is a function of the growth rate of the recipient creates a potential endogeneity bias. This problem has been recognized by some of the previous literature (Clemens et al. (2004), Easterly (2003), Easterly et al. (2004) and Hansen and Tarp (2002).

To deal with endogeneity, the growth equation is estimated using two-stage least squares (2SLS). An array of instruments for aid have been utilized in the existing literature, each having its merits and drawbacks. This paper chooses to follow the strategy employed by Rajan and Subramanian (2006) who build and instrument based on political, historic and cultural links between donor and recipient. The authors exploit the fact that the motives for extending aid are often non-economic in nature and their key assumption is that non-economically-motivated aid is unlikely to be disbursed based on economic performance. Several studies incorporated a similar line of argument 
to explain aid flows (Alesina and Dollar, 2001; Barro and Lee, 2004), albeit without continuing to develop instruments for aid on that basis, as has been done in the paper by Rajan and Subramanian (2006).

The instrument is built in the following manner. First, a donor (d) allocates aid to a recipient (r) according to the following equation:

$$
\begin{aligned}
\theta d r t & =\beta 0+\beta 1 \text { Common Colony } d r+\beta 2 \text { Common Colony UKdr } \\
& +\beta 3 \text { Common Colony FRAdr }+\beta 4 \text { Common Colony SPA } d r \\
& +\beta 5 \text { Common Colony PORdr }+\mathrm{v} d r t
\end{aligned}
$$

$\theta d r t$ is the aid share extended to recipient (r) by donor country (d) in year (t). Common Colony takes a value one if the recipient was ever a colony of the donor, Common Colony UK, Common Colony FRA, Common Colony SPA and Common Colony POR assume a value of one if the recipient was ever a colony of the U.K., France, Spain and Portugal, respectively. A crucial identifying assumption is that the right-hand side variables in the above equation proxy for motives for disbursing aid which are uncorrelated with the recipient country's economic performance.

Second, exogenous variation stemming from the donor countries' macroeconomic conditions is extracted by estimating the following equation.

$$
\mathrm{A}_{d t}=\alpha_{0}+\alpha_{1} \text { Unemployment }_{d t}+\alpha_{2} C A / G D P_{d t}+\alpha_{3} \text { Share Prices }_{d t}+\varepsilon_{d t}
$$

$\mathrm{A}_{d t}$ is the total aid to GDP ratio of donor country (d) in year (t), Unemployment Un $_{d t}$ is the unemployment rate in donor country (d) in year (t), $C A / G D P_{d t}$ is the current account over GDP in donor country (d) in year (t) and Share Prices indicate share price indices in donor country (d) in year ( $t$ ). The reasoning behind the above equation is that the more favorable the macroeconomic conditions in the donor country are, the higher the willingness of the donor to extend aid.

Third, the predicted values $\hat{A}_{d t}$ and $\hat{\theta}_{d r t}$ from equations (2) and (3) are used to calculate the instrument as follows. 


$$
\hat{A}_{r t}=\frac{\sum_{d} G D P_{d t} \hat{A}_{d t} \hat{\theta}_{d r t}}{G D P_{r t}}
$$

Finally, the predicted aid share $\hat{A}_{r t}$ is averaged over 4-year periods and used as the instrument for foreign aid. To estimate the above equations, data on colonial relationships were obtained from the Correlates of War database while macroeconomic data regarding the donor countries were taken from the OECD database.

\section{Empirical results and analysis}

Table 1 reports the empirical results for the four-period panel regressions over the period 1966-2001. Most importantly, the variables of interest Aid/GDP and Aid Volatility both enter significantly in the OLS regression (Column 1), even at a stringent 1 percent significance level. While Aid/GDP has a positive coefficient, Aid Volatility has a negative one. These results imply that while foreign aid is conducive to economic growth, the volatility of aid is not and is in fact negatively related to it. The positive sign

of the aid variable contrast with the majority of studies discussed in Section 2; some of them have indeed found a positive coefficient of aid, but only once it was interacted with other variables such as quality-of-policy indicators.

Turning to the rest of the variables estimated, the significant variables using OLS are institutional quality, initial GDP, the regional dummies, inflation, tropical area fraction, ethnic fractionalization, investment and population growth. The latter enters with a sign opposite to what was previously anticipated while the rest have the intuitive signs. Financial depth, political instability and schooling all have insignificant coefficients, with schooling even exhibiting an unexpected negative sign.

The apparent negative sign of the schooling coefficient can perhaps be explained by the data quality as high-quality data on years of scooling achieved in developing countries is difficult if not impossible to obtain to any degree of accuracy. Anyhow, the coefficient is negative, but not significant. The negative coefficient of the population growth variable may be explained by the higher investment requirements necessitated by a larger and younger population. 
Table 1 - Growth regressions

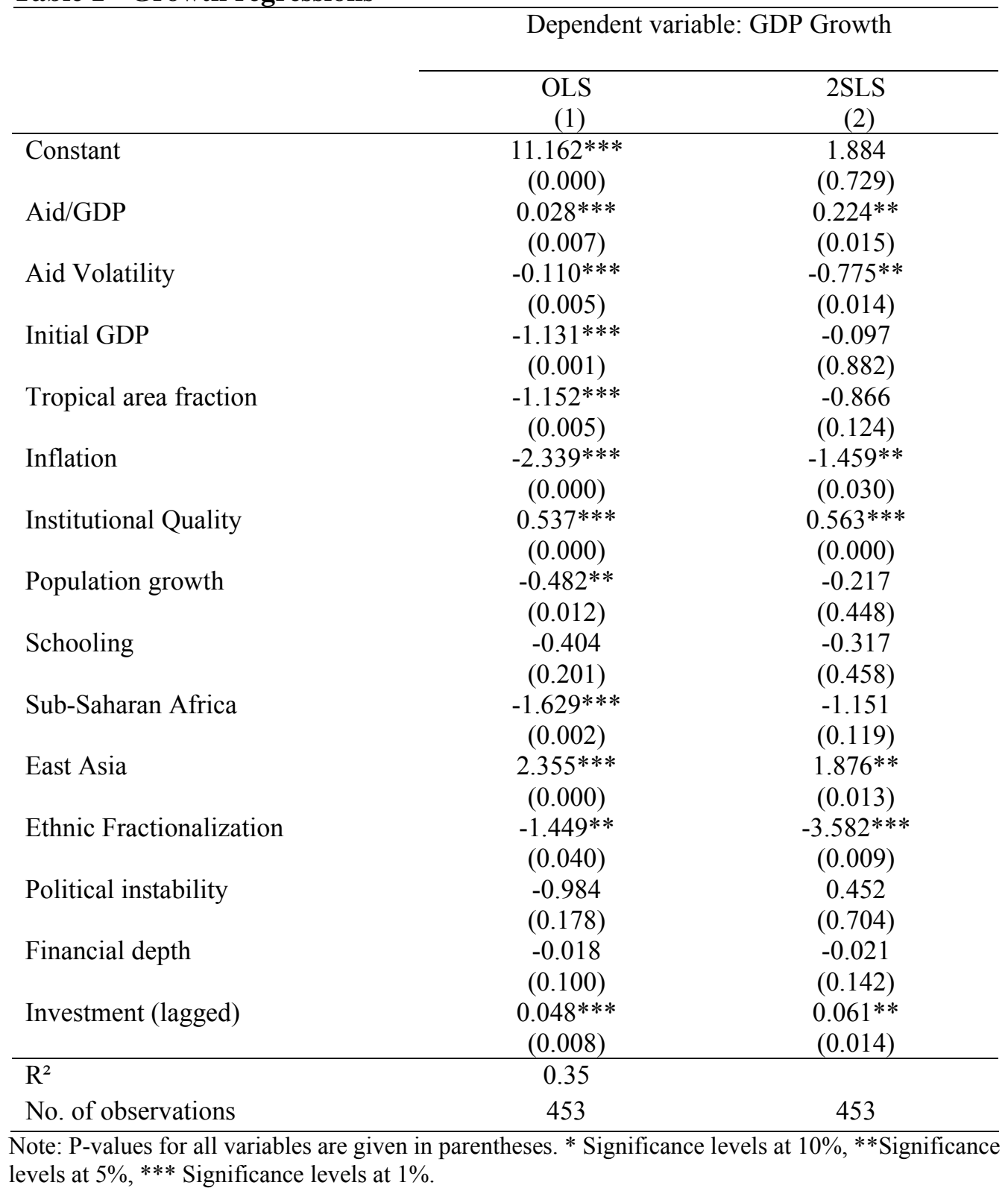

The positive relationship between aid and growth in Model 1, however, does not say much about the direction of causality due to the potential endogeneity problem discussed earlier. Hence, 2SLS estimations were performed; these are in Column 2.

The coefficients of Aid/GDP and Aid Volatility remain significant, albeit at a lower but still customary significance level of 5 percent. The signs of the various coefficients do not change compared to the OLS specification resultsbut the coefficient 
values become considerably larger in magnitude. Other variables which remain significant include inflation, institutional quality, ethnic fractionalization, investment and the regional dummies, all with the expected sign.

The 2SLS estimation indicates that foreign aid has a positive impact on economic growth while the volatility of aid flows is detrimental to it. A Durbin - WuHausman chi-square test was subsequently conducted to test for the endogeneity of the aid variable. The null hypothesis of the exogeneity of foreign aid was rejected at a 1 percent significance level suggesting that this variable is indeed endogenous in the model and that the 2SLS estimation is preferred over OLS. ${ }^{5}$

\subsection{Robustness checks}

This section presents the results of a set of robustness checks performed on the core results. The checks include testing non-linear effects of aid, the use of different samples and estimating the regressions using fixed and random effects. Each is discussed below.

Hadjimichael et al. (1995) were the first to allow for the presence of nonlinear effects of aid. Non linear effects of aid on growth may be present for several reasons. First, many countries might face absorptive capacity constraints and thus a limited capacity to absorb aid resources. Second, as covered in a previous section, 'Dutch Disease' effects may surface as 'too much' aid may be harmful for the recipient's economic conditions.

In addition to Hadjimichael et al. (1995), various later studies also find evidence of diminishing returns to aid in their aid-growth regressions (Durbarry et al., 1998; Lensink and White, 2001; Hansen and Tarp, 2000, 2001). The possibility of nonlinearities in the aid-growth link should thus be recognized. To investigate this, a squared aid term is included in the regressions and is expected to be negatively related with growth. The results are displayed in Table 2 in Columns 3 and 4. In both the OLS and 2SLS specifications, the coefficient of $(\mathrm{Aid} / G D P)^{2}$ turns up negative but insignificant. Thus, non linear effects of aid do not seem to be present in our sample to a significant degree.

H0: Aid/GDP is exogenous $\chi^{2}=8.637, \mathrm{p}$-value $=0.00321^{5}$ 
Table 2- Robustness checks

\begin{tabular}{|c|c|c|c|c|}
\hline & \multicolumn{4}{|c|}{ Dependent variable: GDP Growth } \\
\hline & OLS & $2 \mathrm{SLS}$ & OLS & 2 SLS \\
\hline & $(1)$ & (2) & $(3)$ & (4) \\
\hline \multirow[t]{2}{*}{ Constant } & $11.162 * * *$ & 1.884 & $10.508 * * *$ & -2.184 \\
\hline & $(0.000)$ & $(0.729)$ & $(0.000)$ & $(0.781)$ \\
\hline \multirow[t]{2}{*}{ Aid/GDP } & $0.028 * * *$ & $0.224 * *$ & $0.032 * * *$ & $-0.244 * *$ \\
\hline & $(0.007)$ & $(0.015)$ & $(0.007)$ & $(0.011)$ \\
\hline \multirow[t]{2}{*}{ Aid Volatility } & $-0.110 * * *$ & $-0.776^{* *}$ & -0.103 & $-0.699 * *$ \\
\hline & $(0.005)$ & $(0.014)$ & $(0.010)$ & $(0.035)$ \\
\hline \multirow[t]{2}{*}{ Initial GDP } & $-1.132 * * *$ & -0.097 & $-1.059 * * *$ & 0.356 \\
\hline & $(0.001)$ & $(0.882)$ & $(0.002)$ & $(0.695)$ \\
\hline \multirow[t]{2}{*}{ Tropical are fraction } & $-1.153 * * *$ & -0.866 & $-1.103 * * *$ & -0.535 \\
\hline & $(0.005)$ & $(0.124)$ & $(0.008)$ & $(0.462)$ \\
\hline \multirow[t]{2}{*}{ Inflation } & $-2.339 * * *$ & $-1.459 * *$ & $-2.361 * * *$ & $-1.651 * *$ \\
\hline & $(0.000)$ & $(0.030)$ & $(0.000)$ & $(0.022)$ \\
\hline \multirow[t]{2}{*}{ Institutional Quality } & $0.537 * * *$ & $0.563 * * *$ & $0.542 * * *$ & $0.596 * * *$ \\
\hline & $(0.000)$ & $(0.000)$ & $(0.000)$ & $(0.000)$ \\
\hline \multirow[t]{2}{*}{ Population growth } & $-0.482 * *$ & -0.216 & $-0.480 * *$ & -0.213 \\
\hline & $(0.012)$ & $(0.448)$ & $(0.012)$ & $(0.452)$ \\
\hline \multirow[t]{2}{*}{ Schooling } & -0.404 & -0.317 & -0.406 & -0.331 \\
\hline & $(0.201)$ & $(0.458)$ & $(0.200)$ & $(0.437)$ \\
\hline \multirow[t]{2}{*}{ Sub-Saharan Africa } & $-1.629 * * *$ & -1.151 & $-1.615 * * *$ & -1.076 \\
\hline & $(0.002)$ & $(0.119)$ & $(0.002)$ & $(0.147)$ \\
\hline \multirow[t]{2}{*}{ East Asia } & $2.355 * * *$ & $1.876 * *$ & $2.276 * * *$ & 1.354 \\
\hline & $(0.000)$ & $(0.013)$ & $(0.000)$ & $(0.195)$ \\
\hline Ethnic & $-1.449 * *$ & $-3.582 * * *$ & $-1.522 * *$ & $-3.987 * * *$ \\
\hline Fractionalization & $(0.040)$ & $(0.009)$ & $(0.032)$ & $(0.007)$ \\
\hline \multirow[t]{2}{*}{ Political instability } & -0.985 & 0.452 & -0.965 & 0.525 \\
\hline & $(0.178)$ & $(0.704)$ & $(0.187)$ & $(0.658)$ \\
\hline \multirow[t]{2}{*}{ Financial depth } & -0.018 & -0.021 & $-0.018 *$ & -0.026 \\
\hline & $(0.100)$ & $(0.142)$ & $(0.090)$ & $(0.103)$ \\
\hline \multirow[t]{2}{*}{ Investment (lagged) } & $0.0481 * * *$ & $0.061 * *$ & $0.049 * *$ & $0.067 * *$ \\
\hline & $(0.008)$ & $(0.014)$ & $(0.007)$ & $(0.011)$ \\
\hline \multirow[t]{2}{*}{$(\mathrm{Aid} / \mathrm{GDP})^{2}$} & & & -0.000 & -0.000 \\
\hline & & & $(0.420)$ & $(0.476)$ \\
\hline $\mathrm{R}^{2}$ & 0.35 & & 0.35 & \\
\hline No. of observations & 453 & 453 & 453 & 453 \\
\hline
\end{tabular}

As a further robustness check, different samples are analyzed. In order to eliminate a possible small-country, bias, countries with a population of less than 500,000 are excluded from the sample, which leaves 131 countries. Columns 1 and 2 in Table 2 contain the results corrected for the small country bias. As is evident, the 
coefficients do not vary much and remain significant at similar levels to the estimates using the full sample. We will therefore continue with the full sample.

The final sensitivity check exploits the advantages of panel data to impose some structure on the assumed covariance matrix. This involves estimating the models using, error co mponent variantsm: fixed effects or random effects. Table 3 presents the results. In the fixed effects model, regional dummy variables were dropped as well as those variables which do not vary over time, ethnic fractionalization, fraction of area in the tropics and institutional quality. Their impact is absorbed into the country-specific time-independent dummies (the "fixed effects")..

In the random effects estimation, the majority of the coefficients remains significant and with the same sign as in the pooled OLS regression reported in Table 1. In the fixed effects, surprizingly, aid becomes insignificant while its volatility is only significant in the regression without instrumentation. Other significant variables in the fixed effect estimations include investment, institutional quality, inflation and initial GDP. The large difference in coefficient significance for the two AID related variables between on the one hand GLS and Random Effects and on the other hand Fixed Effects, is revealing. What it suggests is that relying on over time variation in aid volatility alone to identify its effect on economic growth, is not sufficient. Cross country variation in time averaged volatility (the impact of which is subsumed in the country specific dummies in the FE estimation) is necessary too to arrive at significant results ${ }^{6}$. 
Table 3 - Growth regressions using fixed/random effects

\begin{tabular}{|c|c|c|c|c|}
\hline & \multicolumn{4}{|c|}{ Dependent variable: GDP Growth } \\
\hline & $\begin{array}{l}\text { Random Effects } \\
\text { (1) }\end{array}$ & $\begin{array}{l}\text { Random Effects } \\
\text { 2SLS } \\
\text { (2) }\end{array}$ & $\begin{array}{c}\text { Fixed Effects } \\
\text { (3) }\end{array}$ & $\begin{array}{l}\text { Fixed Effects } \\
\text { 2SLS } \\
\text { (4) }\end{array}$ \\
\hline Constant & $\begin{array}{c}15.391 * * * \\
(0.000)\end{array}$ & $\begin{array}{c}5.754 \\
(0.335)\end{array}$ & $\begin{array}{c}24.448^{* * * *} \\
(0.000)\end{array}$ & $\begin{array}{c}16.827 * * \\
(0.035)\end{array}$ \\
\hline Aid/GDP & $\begin{array}{c}0.024 * * \\
(0.022)\end{array}$ & $\begin{array}{l}0.204 * * \\
(0.023)\end{array}$ & $\begin{array}{c}0.015 \\
(0.190)\end{array}$ & $\begin{array}{c}0.151 \\
(0.144)\end{array}$ \\
\hline Aid Volatility & $\begin{array}{c}-0.112 * * * \\
(0.003)\end{array}$ & $\begin{array}{c}-0.698 * * \\
(0.018)\end{array}$ & $\begin{array}{c}-0.105^{* * * *} \\
(0.009)\end{array}$ & $\begin{array}{l}-0.528 \\
(0.101)\end{array}$ \\
\hline Initial GDP & $\begin{array}{c}-1.629 * * * \\
(0.000)\end{array}$ & $\begin{array}{l}-0.619 \\
(0.369)\end{array}$ & $\begin{array}{c}-3.018 * * * \\
(0.000)\end{array}$ & $\begin{array}{c}-2.328 * * * \\
(0.009)\end{array}$ \\
\hline Tropical are fraction & $\begin{array}{c}-1.443 * * \\
(0.016)\end{array}$ & $\begin{array}{l}-0.942 \\
(0.224)\end{array}$ & & \\
\hline Inflation & $\begin{array}{c}-2.247 * * * \\
(0.000)\end{array}$ & $\begin{array}{l}-1.319^{*} \\
(0.060)\end{array}$ & $\begin{array}{c}-2.282 * * * \\
(0.000)\end{array}$ & $\begin{array}{l}-1.466^{*} \\
(0.070)\end{array}$ \\
\hline Institutional Quality & $\begin{array}{c}0.513 * * * \\
(0.000)\end{array}$ & $\begin{array}{c}0.541 * * * \\
(0.000)\end{array}$ & $\begin{array}{l}0.289^{*} \\
(0.058)\end{array}$ & $\begin{array}{l}0.332 * \\
(0.066)\end{array}$ \\
\hline Population growth & $\begin{array}{l}-0.395^{*} \\
(0.085)\end{array}$ & $\begin{array}{l}-0.135 \\
(0.673)\end{array}$ & $\begin{array}{l}-0.267 \\
(0.406)\end{array}$ & $\begin{array}{l}-0.087 \\
(0.828)\end{array}$ \\
\hline Schooling & $\begin{array}{l}-0.417 \\
(0.266)\end{array}$ & $\begin{array}{l}-0.146 \\
(0.768)\end{array}$ & $\begin{array}{l}-0.166 \\
(0.735)\end{array}$ & $\begin{array}{c}0.069 \\
(0.909)\end{array}$ \\
\hline Sub-Saharan Africa & $\begin{array}{c}-2.002 * * * \\
(0.006)\end{array}$ & $\begin{array}{l}-1.516 \\
(0.103)\end{array}$ & & \\
\hline East Asia & $\begin{array}{c}2.699 * * * \\
(0.001)\end{array}$ & $\begin{array}{l}1.895^{*} \\
(0.065)\end{array}$ & & \\
\hline $\begin{array}{l}\text { Ethnic } \\
\text { Fractionalization }\end{array}$ & $\begin{array}{l}-1.604 \\
(0.121)\end{array}$ & $\begin{array}{c}-3.578 * * \\
(0.026)\end{array}$ & & \\
\hline Political instability & $\begin{array}{l}-1.289^{*} \\
(0.075)\end{array}$ & $\begin{array}{l}-0.233 \\
(0.826)\end{array}$ & $\begin{array}{c}-1.547 * * \\
(0.040)\end{array}$ & $\begin{array}{l}-0.940 \\
(0.343)\end{array}$ \\
\hline Financial depth & $\begin{array}{l}-0.022 * \\
(0.097)\end{array}$ & $\begin{array}{l}-0.025 \\
(0.127)\end{array}$ & $\begin{array}{l}-0.017 \\
(0.352)\end{array}$ & $\begin{array}{l}-0.014 \\
(0.515)\end{array}$ \\
\hline Investment (lagged) & $\begin{array}{c}0.049 * * \\
(0.016)\end{array}$ & $\begin{array}{l}0.074 * * \\
(0.018)\end{array}$ & $\begin{array}{l}0.045^{*} \\
(0.063)\end{array}$ & $\begin{array}{c}0.077^{* *} \\
(0.038)\end{array}$ \\
\hline $\mathrm{R}^{2}$ & 0.34 & 0.1934 & 0.0179 & 0.0386 \\
\hline No. of observations & 453 & 453 & 453 & 453 \\
\hline
\end{tabular}




\section{Channels through which aid impacts growth}

A logical next step is to investigate channels through which effects take place. The underlying theoretical models point to investment as being the principal factor through which aid effects growth. Since the regressions sofar included investment as an explanatory variable, that potential channel of impact was excluded. The aim of this section is therefore to test if aid and its volatility also have an impact on investment, not to identify the determinants of investment in a fully specified model. Accordingly, the following simple investment regression is estimated.

$$
\begin{gathered}
\text { Investment } / G D P= \\
\qquad+\beta 1 \text { Aid } / G D P+\beta 2 \text { Aid Volatility }+\beta 3 \text { Schooling }+\beta 4 \\
\\
\text { Quality }+\beta 8 \text { Regional Dummies }+\mu
\end{gathered}
$$

The variables of interest, Aid/GDP and Aid Volatility appear negative but insignificant as is shown in Table 4. This is in contrast to the findings of Lensink and Morrissey (2000) who find that once they control for the volatility of aid, aid is positive and significant in their investment regressions. One explanation for the difference might be that Lensink and Morrissey include only unanticipated volatility, while we focus on total measured volatility. Of course we also use more data and information over time.

The openness and institutional quality variables have highly significant coefficients reflecting the notion that openness to trade and sound institutions spur investment. Further highly significant variables include the East Asia and sub-Saharan Africa dummies, which enter with the anticipated signs.

In view of the apparent insignificant relationship between investment and the foreign aid variables, an additional channel of the impact of aid on growth is explored consumption. It is possible that the diversion of aid from investment to consumption undermines the effectiveness of foreign aid. According to the widely cited study by Boone (1996), foreign aid is not directed towards investment, but largely towards consumption. In a cross-country analysis Boone (1996) finds no significant correlation between aid and investment but finds a positive and significant impact of aid on private 
as well as public consumption. These results imply that most foreign aid flows go to consumption as well as increase the size of government ${ }^{7}$.

Table 4 - Investment and consumption regressions

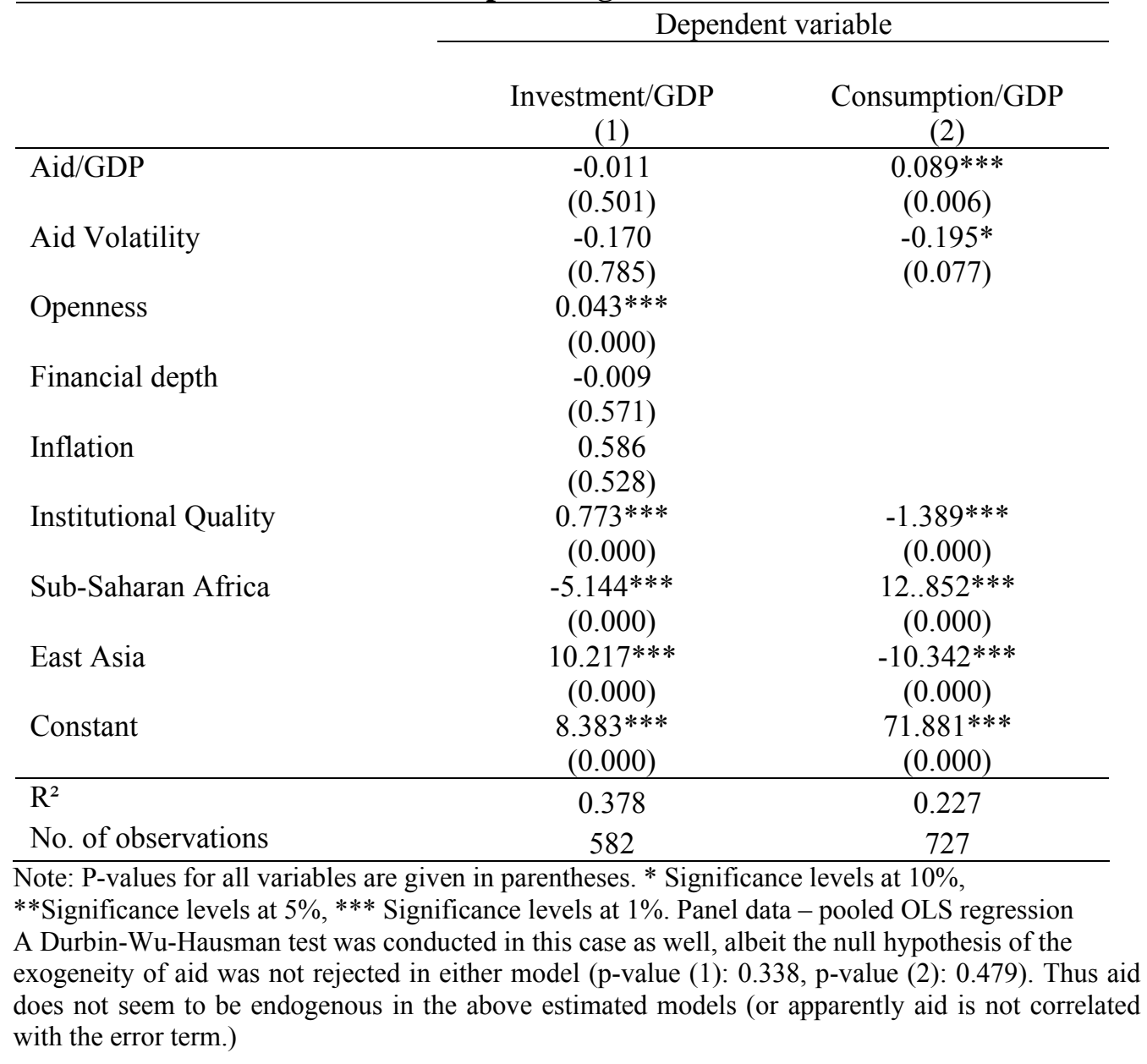

Dollar and Easterly (1999) test the links between aid and investment in Africa and find a positive and significant relationship between aid and investment in 8 countries, but a negative and significant relationship in 12 countries. Hence, the authors argue that aid does not necessarily finance investment. In a separate study Easterly (1999) produces similar results. Easterly (1999) examines the link between investment and foreign aid in 88 countries and finds that only 6 of the 88 reveal a positive and to private investment. That may explain the insignificance of aid in total investment equations. 
significant coefficient of aid. In light of the findings by the above studies and in a similar manner to the investment regression, the following consumption equation is estimated.

$$
\begin{aligned}
\text { Consumption } / G D P= & \alpha+\beta 1 \text { Aid/GDP }+\beta 2 \text { Aid Volatility }+\beta 3 \text { Openness } \\
& +\beta 4 \text { Ethnic Fractionalization }+\beta 5 \text { Institutional Quality } \\
& +\beta 6 \text { Regional Dummies }+\mu
\end{aligned}
$$

Unlike the investment regression, aid and the volatility of aid both enter significantly in the consumption model. These results point to the potential fungibility of aid. These results could indicate that aid recipients reduce their own resources in the sector which receives aid and transfer those freeed up resources to other uses, exploiting the fungeability of aid. In this way, governments free resources for spending on current consumption. This may but does not need to be a negative thing. Supplementing private consumption may have a positive insurance value if it mostly happens in bad macroeconomic circumstances, which seems likely. And supplementing government consumption will take on a less negative connotation than it usually gets once one realizes that under standard accounting conventions expenditure on for example teachers salaries or more generally education counts as government consumption. There may of course be sustainability issues if that is indeed what takes place.

If it is government expenditure that profits mostly, there is a channel that might work out negatively, through corruption. Aid through this channel could fuel corruption among government officials seeking to personally benefit from the disbursed funds. As economic growth may well be (negatively) influenced by corruption, it is important to understand the link between foreign aid and corruption. If it is indeed the case that aid resources facilitate corruption behavior, policy implications should be derived accordingly with the aim of minimizing such behavior. This is important for a variety of reasons. Apart from distorting the economic and financial environment, corruption also lowers the efficiency of government and thereby threatens foreign investment.

As a final test, corruption is thus regressed on aid, aid volatility and other variables. Again, the aim is not to identify the determinants of corruption in a fully 
specified model, but to test if aid and its volatility influence corruption. Thus, the following equation was estimated (results in Table 5 below):

$$
\begin{aligned}
\text { Corruption }= & \alpha+\beta 1 \text { Aid } / G D P+\beta 2 \text { Aid Volatility }+\beta 3 \text { Ethnic Fractionalization } \\
& +\beta 4 \text { Schooling }+\beta 5 \text { Log (Population })+\beta 6 \text { Inflation }+\mu
\end{aligned}
$$

Table 5 - Corruption regressions

\begin{tabular}{lcc}
\hline & \multicolumn{2}{c}{ Dependent variable } \\
\cline { 2 - 3 } & Corruption index & Corruption index \\
& OLS & 2 SLS \\
\hline Aid/GDP & $0.009^{*}$ & $(1)$ \\
Aid Volatility & $(0.091)$ & $0.043^{* *}$ \\
& $-0.037^{*}$ & $(0.018)$ \\
Ethnic Fractionalization & $(0.087)$ & $(0.014)$ \\
& -0.343 & $-0.792^{* *}$ \\
Inflation & $(0.238)$ & $(0.041)$ \\
& $0.453^{* * *}$ & $0.646^{* * *}$ \\
Schooling & $(0.009)$ & $(0.002)$ \\
& $0.357^{* * *}$ & $0.497^{* * *}$ \\
Log (population) & $(0.001)$ & $(0.000)$ \\
& -0.022 & 0.098 \\
Constant & $(0.700)$ & $(0.175)$ \\
& $2.867^{* * *}$ & $3.879^{* * *}$ \\
& $(0.001)$ & $(0.000)$ \\
$\mathrm{R}^{2}$ & & \\
No. of observations & 0.1073 & 215 \\
\hline Note: P-values for all variables are given in parentheses. * Significance levels at $10 \%$, \\
**Significance levels at 5\%, *** Significance levels at $1 \%$. \\
Corruption index: six point scale, higher points means less corruption.
\end{tabular}

Since foreign aid may be endogenous in the above model, a two-stage-least-squares estimation is also necessary. Corruption may influence donors' decisions and may deter them from extending aid to those countries with high levels of corruption, as they this can be viewed as a waste, or inefficient use of aid resources. A Durbin-Wu-Hausman chi-square test was conducted and the null of the exogeneity of the aid variable was rejected at a 5 percent significance level indicating the preference for the 2 SLS variant in Table $5^{8}$ 
Table 5 demonstrates that in both the OLS and the 2SLS, aid and its volatility appear significant, although again with contrasting signs. Corruption is measured on a 6-point scale, with the higher points given to the least corrupt countries. Thus, the positive coefficient of the aid variable indicates that more aid actually leads to lower corruption behavior by recipient governments while the volatility of aid does the opposite and fuels corruption. The latter is plausible, as on-and-off aid flows discourage the use of aid in structural useful investment projects. The negative impact of aid flows on the level of corruption is certainly not conform prior expectations. The higher the ethnic fractionalization in the recipient country, the higher the corruption levels are likely to be and the higher the education levels, the lower the corruption. Population size is insignificant in the regression and inflation is significant and negatively related to corruption suggesting that higher inflation levels lead to less corruption. There may just be less to steal as high inflation also reduces economic efficiency. While further exploration of these results on both an empirical and a theoretical level is tempting, it is beyond the scope of this paper and should be the subject of further research.

\section{Conclusion}

While the question whether foreign aid helps countries grow has been immensely covered in the literature, foreign aid's effectiveness in promoting economic growth remains mired in controversy. Few studies have explored aid flow volatility; empirical papers on the topic are scarce. Among them, most focus on examining the extent to which aid flows are volatile while others mostly study aid volatility and its effects on variables such as investment, consumption, government behavior and other factors. The aim of this paper was thus to fill this gap by directly testing the relationship between economic growth and the volatility of foreign aid by means of a four-year panel estimation.

Numerous studies have cast doubt on the positive impact of aid on growth. Yet the empirical analysis of this paper supports the view that aid has a positive effect on growth: in fact, once the volatility of aid is controlled for, aid benefits economic growth.

Correspondingly, volatile aid flows are found to be significantly but negatively related 
to growth. The results further point to investment and institutional quality as being of primary importance to growth.

While no significant link was found between investment and foreign aid, a positive correlation was found between aid and consumption and a negative link between aid volatility and consumption. The results reflect the fact that rather than promoting economic growth through investment behavior, aid is often diverted to consumption. This does not need to be a negative result: offsetting negative shocks through use of aid-supplied resources may provide useful insurance services, while under standard accounting conventions government consumption includes items like teacher salaries, which may contribute to human capital accummulation and so indirectly to growth. These results merit further research. Chauvett and Guillaumont (2008) demonstrated that aid may be beneficial when acting as a shockabsorber. Our results indicate that, instead, aid has become a source of volatility rather than insuring against it, and in that way has become inimical to economic growth. Finally, corruption was regressed on aid and aid volatility. The results suggest that aid volatility is positively related to corruption in recipient countries, but, possibly surprizingly, that the volume of aid is negatively correlated with corruption. While these are interesting results, investigating them further is beyond the scope of this paper. Additional research is clearly necessary to more thoroughly explore the channels through which foreign aid impacts economic growth and establish policy implications accordingly.

Since volatility in aid flows may be caused by fluctuations in economic conditions in donor countries or alternatively by shocks in the recipient economy, identifying the nature of this volatility is also vital in order to develop appropriate policies with regards to foreign aid. In the former case, for example, more stable donorrecipient relationships should be the main objective. Thus, this paper wishes to draw attention to the importance of further investigation of the underlying causes of volatile aid flows. Such research will hopefully enhance our understanding of the aid-growth relationship.

\section{References}

Adam, Christopher, and Stephen A. O'Connell, (1999). Aid, taxation and development in Sub Saharan Africa. Economics and Politics, Vol. 11, November, pp. 225-53. 
Alan Heston, Robert Summers and Bettina Aten, Penn World Table Version 6.2, Center for International Comparisons of Production, Income and Prices at the University of Pennsylvania, September 2006

Alesina, Alberto and David Dollar (2000). Who gives foreign aid to whom and why? Journal of Economic Growth 5 (1): pp. 33-63.

Ali, M. and Isse, H.S. (2005). An empirical analysis of the effect of aid on growth. International Advances in Economic Research 11: 1-11.

Barro, R. J. (1991). Economic growth in a cross section of countries. Quarterly Journal of Economics, Vol. 106, pp. 407-443.

Barro, Robert J., and Jong-Wha Lee, (2004). IMF Programs: who is chosen and what are the effects? mimeo.

Benhabib and Siegel (1995), “**”, Journal of Monetary Economics

Bleaney, M. F. (1996). Macroeconomic stability, investment and growth in developing countries, Journal of Development Economics, Vol. 48, pp. 461-477.

Bloom, D. and J. D. Sachs. (1998). Geography, demography and economic growth in Africa. Brookings Papers on Economic Activity 2: 207-73.

Boone, P. (1996). Politics and the effectiveness of foreign aid. European Economic Review, Vol. 40, pp. 289-328.

Buliřr, A. and A.J. Hamann (2003). Aid volatility: an empirical assessment. IMF Staff Papers, 50(1), 64-89.

Bulír, A. and A.J. Hamann (2005). Volatility of development aid: from the frying pan into the fire? IMF Staff Papers.

Burnside and Dollar (1997) Aid, policies, and growth. Policy Research Working Paper No. 1777, Washington, World Bank

Burnside, C. and D. Dollar. (2004). Aid, policies, and growth: revisiting the evidence. Policy Research Working Paper O-2834. World Bank, Washington, DC.

Caballero, R. (2007), "Persistent Appreciations and Overshooting: a Normative Analysis”, NBER Working Paper 13077

Celasun, IMF study in EP

Chauvet, L. and P. Guillaumont. (2002). Aid and growth revisited: policy, economic vulnerability and political Instability." Paper presented at the Annual Bank Conference on Development Economics: Towards Pro-poor Policies, Oslo

Chenery, H. and Strout, M. (1966). Foreign assistance and economic development. 
The American Economic Review. 66, pp. 679-733.

Clemens Michael A., Steven Radelet and Rikhil Bhavnani (2004). Counting chickens when they hatch: the short term effect of aid on growth. Working Paper No. 44, Center for Global Development

Correlates of War 2 Project. Colonial/Dependency Contiguity Data, 1816-2002.Version 3.0.

Cukierman

Dalgaard, Carl-Johan, Henrik Hansen and Finn Tarp (2004). On the empirics of foreign aid and growth. The Economic Journal, Vol. 114(496): pp. 191-216.

Dixit, Pindyck ***

Dowling, J.M. and U. Hiemenz (1983). Aid, savings, and growth in the Asian region. The Developing Economies, Vol. 21, No.1, pp. 1-13

Durbarry, R., N. Gemmell, and D. Greenaway. (1998). New evidence on the impact of foreign aid on economic growth.” CREDIT Research Paper 98r8. University of Nottingham, Nottingham.

Easterly, W. (1993). How much do distortions affect growth. Journal of Monetary Economics, Vol. 32, pp. 187-212.

Easterly, W. and S. Rebelo (1993). Fiscal policy and economic growth: an empirical analysis. Journal of Monetary Economics. 32, 417-458.

Easterly, William, and Ross Levine, (2003) Tropics, germs, and crops: how endowment influence economic development. Journal of Monetary Economics, Vol. 50, No. 1, pp. 3-39.

Easterly, William, Ross Levine, and David Roodman (2004). New data, new doubts: a comment on Burnside and Dollar's 'aid, policies, and growth'. American Economic Review, forthcoming.

Fischer, S. (1991). Macroeconomics, development, and growth. NBER Macroeconomics Annual, pp. 329-364.

Fischer, S. (1993). The role of macroeconomics factors in growth. Journal of Monetary Economics, Vol. 32, pp. 485-512.

Gemmell, N. and M. McGillivray, (1998). Aid and tax instability and the government budget constraint in developing countries. CREDIT Research Paper 98/1, University of Nottingham.

Hadjimichael, M.T et al. (1995). Sub-Saharan Africa growth, savings, and investment, 
International Monetary Fund Occasional Paper 1986-1993, No.118, Washington D.C

Hansen, Henrik, and Finn Tarp (2001). Aid and growth regressions. Journal of Development Economics, 64: pp. 547-

International Monetary Fund, (2007). Fiscal Policy Response to Scaled-Up Aid.

Lensink, R. and O. Morrissey, (1999) Uncertainty of aid inflows and the aid-growth relationship. CREDIT Research Paper 99/3, University of Nottingham

Lensink, R. and O. Morrissey, (2000). Aid instability as a measure of uncertainty and the positive impact of aid on growth. Journal of Development Studies,36:3,31 49

Levy, V. (1988). Aid and growth in sub-Saharan Africa: the recent experience. European Economic Review, 32, 9, 1988, pp. 1777Y95

Moreira, S. (2003). Evaluating the impact of foreign aid on economic growth: a cross country study (1970-1998). Paper presented at the 15th Annual Meeting on Socio-Economics June 26-28, 2003 (Session B / D)

Mosley, P. (1980). Aid, savings and growth revisited. Bulletin of the Oxford University Institute of Economics and Statistics. 42, 2, 1980, pp. 79-95.

Mosley, P., J. Hudson and S. Horrell (1987). Aid, the public sector and the market in less developed countries. Economic Journal, Vol. 97, pp. 616-641.

Pallage, S., Robe, M. and Bérubé, C. (2004). On the potential of foreign aid as insurance. CIRPEE Working Paper 04-04.

Pallage, S. and Robe, M.A. (2001). Foreign aid and the business cycle. Review of International Economics, 9(4), 641-72.

Papanek, G. (1973). Aid, private foreign investment, savings and growth in less developed countries. Journal of Political Economy, Vol. 81, pp. 120-130.

Rajan, Raghuram, and Arvind Subramanian, (2005). aid and growth: what does the cross-country evidence really show? NBER Working Paper 11513

Rajan, Raghuram, and Arvind Subramanian (2005). What undermines aid's impact on growth? mimeo, IMF, Washington D.C.

Rajan, Raghuram, and Arvind Subramanian (2006). Aid, Dutch disease, and manufacturing growth.

Roodman, David (2004). The anarchy of numbers: aid, development, and crosscountry empirics. Center for Global Development, Washington, DC. 
Sachs, J. D. (2001). Tropical underdevelopment. Working Paper W8119. National Bureau of Economic Research, Cambridge, MA.

Sachs, J. D. (2003). Institutions don't rule: direct effects of geography on per capita income. Working Paper W9490. National Bureau of Economic Research, Cambridge, MA.

Singh, R. (1985). State intervention, foreign economic aid, savings, and growth in LDCs: some recent evidence. Kyklos, 38, pp. 216-232.

Voivodas, C.S. (1973). Exports, foreign capital inflow and economic growth. Journal of International Economics, Vol. 3, pp. 337-349

White, H., (1992). The macroeconomic impact of development aid: a critical survey. Journal of Development Studies, Vol.28, No.2, pp.163-240

Wijnbergen, S. van (1984), “The Dutch Disease: a Disease After All?”,, Economic Journal.

Appendix 1. Descriptive statistics 
Table 6 - Correlations matrix

\begin{tabular}{|c|c|c|c|c|c|c|c|c|c|c|c|c|c|}
\hline & Aid & Vol & Inv & Open & Ethnf & Icrge & Infl & $\begin{array}{l}\text { Initial } \\
\text { GDP }\end{array}$ & $\begin{array}{l}\mathrm{M} 2 / \mathrm{GD} \\
\mathrm{P}\end{array}$ & Piustab & $\begin{array}{l}\text { Popgro } \\
\text { wth }\end{array}$ & $\begin{array}{l}\text { Schooli } \\
\text { ng }\end{array}$ & Tropic \\
\hline Aid & 1.0000 & & & & & & & & & & & & \\
\hline Vol & 0.9299 & 1.0000 & & & & & & & & & & & \\
\hline Inv & -0.1336 & -0.1109 & 1.0000 & & & & & & & & & & \\
\hline Open & -0.1652 & -0.1785 & 0.3747 & 1.0000 & & & & & & & & & \\
\hline Ethnf & 0.3428 & 0.2658 & $\begin{array}{l}-0.1616 \\
\end{array}$ & 0.0283 & 1.0000 & & & & & & & & \\
\hline Icrge & $\begin{array}{l}-0.1109 \\
\end{array}$ & -0.0929 & 0.3307 & 0.1719 & $\begin{array}{l}-0.1551 \\
\end{array}$ & 1.0000 & & & & & & & \\
\hline Infl & -0.0226 & 0.0303 & -0.1202 & -0.2899 & -0.0274 & -0.0465 & 1.0000 & & & & & & \\
\hline $\begin{array}{l}\text { Initial } \\
\text { GDP }\end{array}$ & -0.4009 & -0.3224 & 0.4213 & 0.1505 & -0.5410 & 0.3649 & -0.032 & 1.0000 & & & & & \\
\hline M2/GDP & -0.0561 & -0.0387 & 0.3484 & 0.4499 & -0.1888 & 0.2813 & -0.1789 & 0.3799 & 1.0000 & & & & \\
\hline Piustab & 0.0395 & 0.0707 & -0.1448 & -0.1601 & 0.1176 & -0.3009 & 0.1498 & -0.1240 & -0.1502 & 1.0000 & & & \\
\hline Popgrowth & 0.0339 & 0.0282 & -0.1600 & 0.1415 & 0.1810 & -0.2097 & -0.1057 & -0.2272 & -0.063 & -0.0477 & 1.0000 & & \\
\hline Schooling & -0.2309 & -0.1817 & 0.3013 & 0.1632 & -0.3522 & 0.2647 & -0.0002 & 0.6421 & 0.4391 & 0.0054 & -0.3883 & 1.0000 & \\
\hline Tropic & -0.0059 & -0.0531 & -0.1664 & 0.1588 & 0.3519 & -0.0982 & -0.0021 & $\begin{array}{l}-0.3888 \\
\end{array}$ & -0.3592 & 0.1074 & 0.0918 & -0.3201 & 1.0000 \\
\hline
\end{tabular}

(Aid - Aid/GDP, Vol - Aid Volatility, Open - openness, Ethnf - Ethnic fractionalization, Icrge Institutional quality, Pinstab - political instability, Popgrowth - population growth)

Table 7 - Summary statistics

\begin{tabular}{lcccc}
\hline & Mean & Std. Dev. & Min & Max \\
\hline Aid/GDP & 15.90517 & 34.09878 & -.8588731 & 554.7719 \\
Aid Volatility & 33.809008 & 9.9 .153356 & .0000321 & 140.836 \\
Initial GDP & 7.527456 & .923391 & 4.213761 & 10.75552 \\
Tropical are fraction & .5822231 & .4664925 & 0 & 1 \\
Inflation & .1785478 & .3471487 & -.0633278 & 3.878448 \\
Institutional Quality & 4.499589 & 1.894499 & 0 & 10 \\
Population growth & 2.072065 & 1.473498 & -8.657725 & 16.99755 \\
Schooling & .8532884 & .7516486 & .0114 & 4.0038 \\
Ethnic & .4398 & .2922856 & 0 & .93 \\
Fractionalization & & & & \\
Political instability & .1178951 & .2121377 & 0 & 1.654494 \\
Financial depth & 32.8124 & 30.14791 & 2.715482 & 534.5886 \\
Investment & 12.81367 & 8.448374 & 1.16141 & 91.48 \\
Growth & 1.396451 & 5.41933 & 0 & .93 \\
\hline
\end{tabular}


Appendix 2. Country list

\begin{tabular}{|c|c|c|c|}
\hline Afghanistan & Dominica & Macao & Singapore \\
\hline Albania & Dominican Republic & Macedonia & Slovak Republic \\
\hline Algeria & Ecuador & Madagascar & Slovenia \\
\hline Antigua \& Barbuda & Equatorial Guinea & Malawi & Solomon Islands \\
\hline Argentina & Eritrea & Malaysia & Somalia \\
\hline Armenia & Estonia & Maldives & South Africa \\
\hline Azerbaijan & Ethiopia & Mali & Sri Lanka \\
\hline Bahamas, The & Fiji & Malta & St. Kitts \& Nevis \\
\hline Bahrain & Gabon & Mauritania & St. Lucia \\
\hline Bangladesh & Gambia, The & Mauritius & St.Vincent \& Grenadines \\
\hline Barbados & Georgia & Mexico & Sudan \\
\hline Belize & Ghana & Micronesia, Fed. Sts. & Suriname \\
\hline Benin & Grenada & Moldova & Swaziland \\
\hline Bhutan & Guatemala & Mongolia & Syria \\
\hline Bolivia & Guinea & Morocco & Taiwan \\
\hline Bosnia \& Herzegovina & Guinea-Bissau & Mozambique & Tajikistan \\
\hline Botswana & Guyana & Namibia & Tanzania \\
\hline Brazil & Haiti & Nepal & Thailand \\
\hline Brunei & Honduras & Nicaragua & Togo \\
\hline Bulgaria & Hong Kong & Niger & Tonga \\
\hline Burkina Faso & Hungary & Nigeria & Trinidad \&Tobago \\
\hline Burundi & India & Oman & Tunisia \\
\hline Cambodia & Indonesia & Pakistan & Turkey \\
\hline Cameroon & Iran & Palau & Turkmenistan \\
\hline Cape Verde & Iraq & Panama & Uganda \\
\hline Central African Republic & Jamaica & Papua New Guinea & Ukraine \\
\hline Chad & Jordan & Paraguay & United Arab Emirates \\
\hline Chile & Kazakhstan & Peru & Uruguay \\
\hline China & Kenya & Philippines & Uzbekistan \\
\hline Colombia & Kiribati & Poland & Vanuatu \\
\hline Comoros & Korea, Dem. Rep. & Puerto Rico & Venezuela \\
\hline Congo, Dem. Rep. & Korea, Republic of & Romania & Vietnam \\
\hline Congo, Republic of & Kuwait & Rwanda & Yemen \\
\hline Costa Rica & Laos & Samoa & Zambia \\
\hline Cote d'Ivoire & Latvia & Sao Tome and Principe & Zimbabwe \\
\hline Croatia & Lebanon & Saudi Arabia & \\
\hline Cuba & Lesotho & Senegal & \\
\hline Cyprus & Liberia & Serbia \& Montenegro & \\
\hline Czech Republic & Libya & Seychelles & \\
\hline Djibouti & Lithuania & Sierra Leone & \\
\hline
\end{tabular}


Appendix 3.Data set.

$\begin{array}{ll}\begin{array}{l}\text { Variable } \\ \text { Net ODA/GDP }\end{array} & \begin{array}{l}\text { Data Source } \\ \text { OECD-DAC }\end{array} \\ & \\ & \\ & \\ \begin{array}{l}\text { ODA/GDP volatility } \\ \text { Real per capita GDP } \\ \text { growth }\end{array} & \text { Roodman, 2005 } \\ \begin{array}{l}\text { Initial GDP per capita } \\ \text { Ethno-linguistic } \\ \text { fractionalization } \\ \text { Assassinations/capita }\end{array} & \begin{array}{l}\text { Roodman, 2005 } \\ \text { Roodman, 2005 }\end{array} \\ \begin{array}{l}\text { Political Instability, } \\ \text { lagged } \\ \text { Institutional quality }\end{array} & \text { Roodman, 2005 } \\ & \text { Roodman, 2005 } 2005\end{array}$

\begin{tabular}{|c|c|}
\hline M2/GDP, lagged & Roodman, 2005 \\
\hline $\begin{array}{l}\text { Mean years of secondary } \\
\text { schooling }\end{array}$ & Roodman, 2005 \\
\hline Population growth & Roodman, 2005 \\
\hline Tropical area fraction & Roodman, 2005 \\
\hline Inflation & Roodman, 2005 \\
\hline Sub-Saharan Africa & Roodman, 2005 \\
\hline East Asia & Roodman, 2005 \\
\hline Openness & Summer and Heston, 1991 \\
\hline $\begin{array}{l}\text { Investment share of real } \\
\text { GDP }\end{array}$ & Summer and Heston, 1991 \\
\hline $\begin{array}{l}\text { Government share of real } \\
\text { GDP }\end{array}$ & Summer and Heston, 1991 \\
\hline $\begin{array}{l}\text { Consumption share of } \\
\text { real GDP }\end{array}$ & Summer and Heston, 1991 \\
\hline $\begin{array}{l}\text { Common Colony UK, } \\
\text { Fra, Spa, Por }\end{array}$ & Correlates of War Dataset \\
\hline Common Colony, & Correlates of War Dataset \\
\hline Current account balance & OECD dataset \\
\hline Share Price index & OECD dataset \\
\hline Unemployment rate & OECD dataset \\
\hline Corruption & $\begin{array}{l}\text { International Country Risk } \\
\text { Guide (ICRG) database }\end{array}$ \\
\hline
\end{tabular}

Notes

Official Development Assistance (ODA) is defined by the OECD as 'those flows to developing countries and multilateral institutions provided by official agencies, including state and local governments, or by their executive agencies, each transaction of which meets the following tests: i) it is administered with the promotion of the economic development and welfare of developing countries as its main objective; and ii) it is concessional in character and conveys a grant element of at least 25 per cent'. (Constant US dollars)

Author's calculations (standard deviation of net ODA)

Natural logarithm of GDP/capita for first year of period Probability that two randomly chosen individuals differ ethnically

number per million population of political assassinations per year

Simple average of ASSAS and revolutions/year

Continuous variable between 0 and 10, commonly known as the International Country Risk Guide (ICRGE) indicator. Average of corruption, bereaucratic quality and rule of law indicators published in Political Risk Group's IRIS III dataset.

Mean years of secondary schooling of those over 25 years of age

Fraction of a country's area that is located in the tropics $\log (1+$ inflation $)$

Dummy for countries in the southern Sahara

Dummy for China, Indonesia, South Korea, Malaysia, Philippines, Singapore and Thailand Exports + Imports/GDP

Dummy variables equal to one if the recipient was ever a colony of U.K., France, Spain and Portugal Dummy variable equal to one if the recipient was ever a colony of the donor.

This is an assessment of corruption within the political system. Points (up to 6) are assigned by $I C R G$ editors on the basis of a series of pre-set questions. The lower the points assigned, the higher the risk and vice versa. 
Appendix 4. Additional specifications

The following table displays the various growth specifications estimated before arriving at the preferred specification reported in Table 1 (or column 4 in table 7 below).

Table 8 - OLS Growth regressions

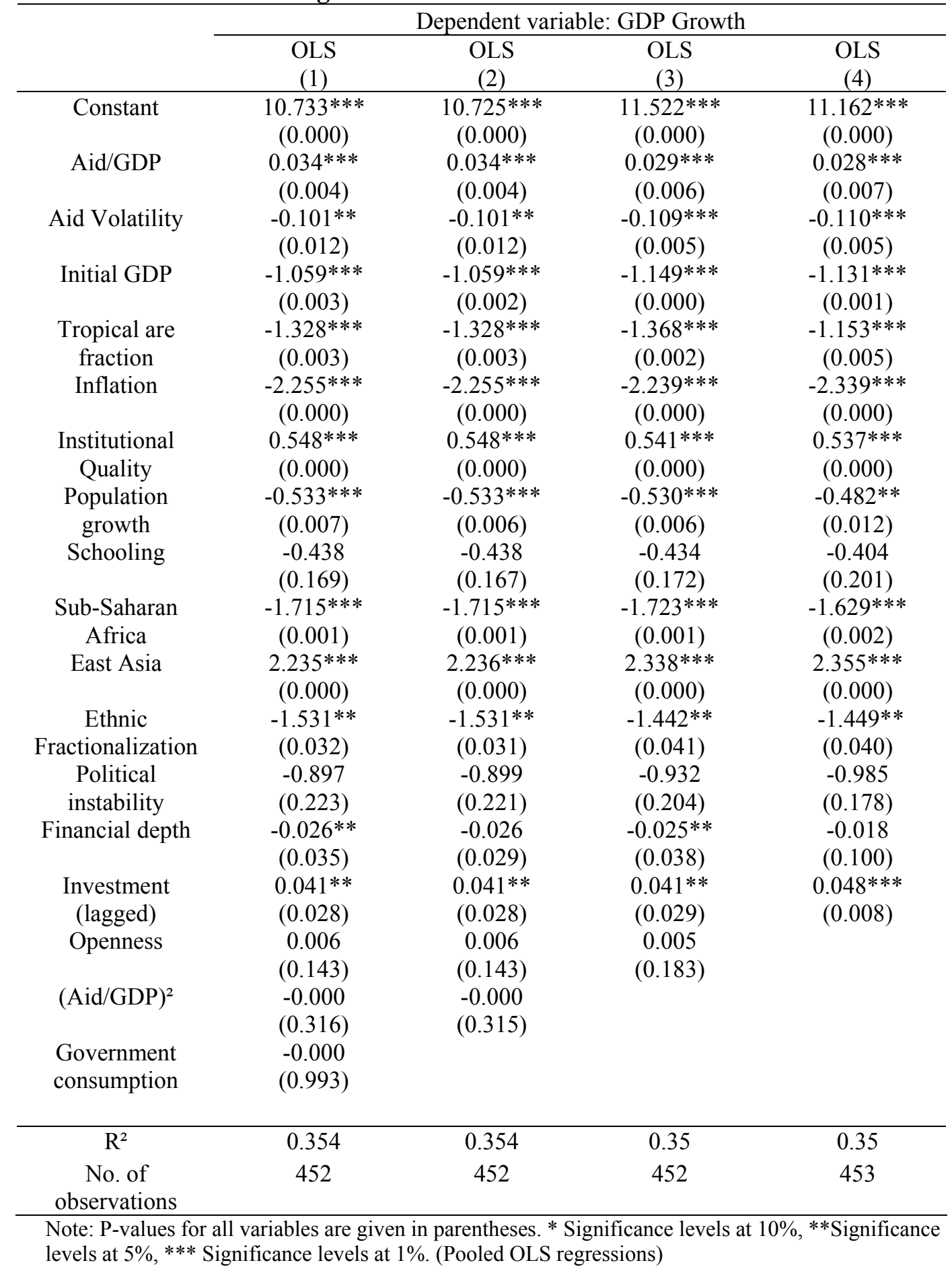

